\title{
The Construction of Practical Teaching System for Public Management Majors in Colleges and Universities
}

\author{
Jianwu $\mathrm{Wu}^{*}$
}

School of Politics \& Law and Public Administration, Hubei University, Wuhan 430062, China

*Corresponding author. Email: wujianwu@hubu.edu.cn

\begin{abstract}
Practical teaching is an important part of public administration majors teaching, and it is the main method and means to cultivate students' practical ability and innovative ability. This paper discusses the construction of the practice teaching system of public administration majors, constructs a "four modules" practical teaching system consistent with the professional training objectives, and proposes corresponding countermeasures to help improve the quality of practice teaching for public management majors.
\end{abstract}

Keywords: Public administration majors, practical teaching system, talent training

\section{INTRODUCTION}

The public administration majors are established to meet the requirements of modern, scientific and professional of social public administration [1], public administration majors mainly include public utilities administration, administrative administration, labor and social security and other specific majors. Although the research directions of different majors are different, these majors are derived from public administration practices and serve public administration practices [2], which are highly practical and applicable. Due to the influence of traditional teaching concepts and teaching resources, the current public administration majors have problems such as the lag of practical teaching concepts, the unreasonable setting of practical teaching plans, the lack of laboratory construction and the construction of practice bases. Therefore, it is urgent to innovate the practical teaching mode of public administration majors and construct a reasonable and perfect practical teaching system to enhance students' practical ability and innovative ability.

\section{PROBLEMS IN THE PRACTICE TEACHING OF PUBLIC ADMINISTRATION MAJORS}

\footnotetext{
Practical teaching of public administration majors refers to various teaching forms in which students carry out professional ability training under the guidance of teachers according to the unified arrangement of teaching plans, so as to improve their practical ability and innovative ability[3] , including experiments, classroom training, second classroom activities, thesis design, graduation internships and other social practices. Due to the short construction time of public administration majors, there are many problems in practical teaching, mainly reflected in the following aspects:
}

\subsection{The Practice Teaching Plan Is Not Reasonable}

The credits for the practice teaching of public administration majors in most domestic universities are only about 20 , accounting for only $10 \%$ of the total credits, and the proportion is too low. The curriculum in the teaching plan lays too much emphasis on the teaching of theoretical knowledge and ignores the practical links of internalization and application of these theoretical knowledge, resulting in poor application ability of students and unable to meet the social demand for high-quality application-oriented talents in public administration [4].

\subsection{The Effect of Classroom Training Is Not Ideal}

Because the theoretical teaching of each course occupies most of the class hours, there are only a few class hours left for practical training teaching, which leads to insufficient time for practical training teaching. There are usually only a few class discussions or case studies in a course [5]. In addition, many teachers themselves do not grasp the classroom training teaching is not in place, on how to carry out effective and standardized organization is not skilled, so that often make this kind of practical training teaching in the classroom just a form, or have little effect.

\subsection{Laboratory Equipment Cannot Meet the Needs of Experimental Teaching}

Compared with theoretical teaching, the investment in experimental teaching is expensive, not only requires a certain amount of hardware, but also needs to be updated software [6]. Especially under the current informatization 
conditions, if we want to establish a simulated or virtual experimental teaching system, such as e-government process simulation, public decision-making process simulation, document flow simulation, etc., these inputs are a lot of expenses. Because the funds used in the experimental teaching of liberal arts are often very limited, there are problems such as lack of teaching equipment and backward teaching software in the laboratory, which may result in some experimental courses not being able to be opened or completed in quality and quantity.

\subsection{The Effect of Off-Campus Internship Is Not Ideal}

Because the existing practice curriculum and practice teaching content is relatively outdated and inconsistent with the needs of internship units and other reasons, when we take the post internship and other methods for graduation internship, many internship units believe that the students' professional skills are insufficient, plus some students internships don't pay attention to them, and they often don't attend work. Therefore, internship units often only assign some immaterial and simple work to interns, which makes it impossible for students to truly improve their professional competence and quality through internship, and also affects the continuity and effectiveness of cooperation between internship units and schools.

\subsection{The Strength of the Practical Teaching Staff Is Relatively Weak}

Among the teachers majoring in public administration, only a small number of "double-qualified" teachers have relevant work experience, and most of them work directly in universities after graduation from the campus. These teachers have rich theoretical knowledge, but lack of relevant practical skills training and practical experience, their practical teaching ability is insufficient, so it is difficult to provide effective practical guidance for students[7].On the other hand, teachers' participation in practical teaching often requires higher time and economic costs than theoretical teaching, which also affects the enthusiasm of teachers to participate in practical teaching to a certain extent [8]

In view of the above problems, colleges and universities urgently need to strengthen the study of public administration majors practice teaching, innovative practice teaching mode, and actively explore the practical teaching system suitable for the school, in order to help improve the quality of public administration majors practice teaching.

\section{THE GOAL OF THE CONSTRUCTION OF PRACTICAL TEACHINGSYSTEM FOR PUBLIC ADMINISTRATION MAJORS}

Practical teaching refers to the teaching process setting up in the process of teaching, which is based on student activities and supplemented by teacher counseling, and strengthens students' practical ability training through various forms. Therefore, this paper proposes that the goal of the construction of the public administration majors practice teaching system is to train high-level, applied and compound talents who can manage in enterprises and public institutions. Through practical teaching activities, students can be equipped with practical abilities such as professional knowledge application ability, ability to analyze and solve practical problems of public administration, and promote students consolidate and deepen their understanding of the basic knowledge, theories and methods of public administration, and strengthen the training of students' professional skills in office automation, e-government, interpersonal communication, investigation and research, document writing, statistical analysis and organizational management.

\section{THOUGHTS ON THE CONSTRUCTION OF PRACTICAL TEACHING SYSTEM FOR PUBLIC ADMINISTRATION MAJORS}

According to the requirements of the practical teaching objectives of public administration and according to the cognitive structure of students at each stage of learning, the practical teaching system of the "four modules" of public administration majors is constructed, and the following implementation schemes are proposed.

\subsection{Classroom Training Module}

As a basic form of practical teaching, classroom practice is mainly based on classroom theoretical knowledge, which is conducive to consolidating and strengthening students' understanding and application of classroom theoretical knowledge, and is also conducive to fully mobilizing students' enthusiasm to participate in classroom teaching activities [9]. In addition to ensuring the necessary class hours, classroom training should be diversified in content and form. The main forms of classroom training activities include group discussions, speech debates, case studies, flipping classes and scenario simulations. The courses that can be offered include: public sector human resource administration, public sector performance administration, administration secrets, government etiquette, civil service test topics, social survey principles and methods, and public administration case studies, etc. 


\subsection{Experimental Teaching Module}

Public administration experiment teaching refers to the experimental environment that the classroom teacher builds similar to public administration practice through perfect laboratory facilities and virtual simulation software, allowing students to immerse themselves in the simulation or virtual administration practice situation to experience the administration process and feel the administration practice, and then cultivate their professional skills and comprehensive quality teaching mode [10].

The school may encourage the experimental teachers to set up experimental courses, develop experimental projects, compile experimental textbooks, etc., and provide technical support and guidance for the teaching teachers to apply for the project [11], which realize the effective connection between teaching and technical means in the course of experiment. The experimental courses that can be opened include: big data administration, word processing and office automation, document writing and processing, quantitative analysis and SPSS application, e-government theory and practice, public crisis administration and urban administration,etc.

\subsection{The Second Class Training Module}

The second class is mainly some practical activities under the guidance of teachers, and are carried out with students as the main body outside the classroom, Such as observation tours, volunteer services (actions), current affairs hot debates, official document writing competitions, academic competitions, challenge cups, and university students' innovative projects ,etc. In the second class, students can be trained and practiced comprehensively in innovation, and it is also a platform for students to show themselves and give play to their creativity.

\subsection{The Internship Module}

The internship module of the public administration majors mainly refers to the actual work of the students in the internship unit or the school under the guidance of the teachers inside and outside the school, such as off-campus graduation internships and in-school internships. The in-school internship mainly refers to cooperation with the school functional departments, logistics groups, libraries and archives departments, and dispatches students to work internships. To a certain extent, it solves the problem that the internship units are difficult to find and the internship content is not correct. Internships in various public sectors outside the university will enable students to master practical management skills and methods, as well as the ability to analyze and solve practical problems in public management, which will be conducive to individual career positioning and planning.

\section{COUNTERMEASURES FOR THE CONSTRUCTION OF PRACTICAL TEACHING SYSTEM FOR PUBLIC ADMINISTRATION MAJORS}

\subsection{Increase the Proportion of Practical Teaching Courses}

It emphasizes the importance of practical teaching to cultivate students' professional knowledge application ability and comprehensive quality ability. When formulating the teaching plan, the credit hours of theoretical courses should be reduced appropriately, and the credit hours of practical courses should be increased to ensure that the credit hours of practical teaching links account for $20 \%$ or more of the total credit. At the same time, it is necessary to emphasize the diversification of classroom teaching forms, which should be organically combined with classroom teaching, case analysis, curriculum design, scenario simulation, social investigation and other practical training forms, so that practice teaching should be integrated into compulsory courses and elective courses to realize the positive interaction between theory teaching and practice teaching.

\subsection{Improve Teachers' Practical Teaching Ability}

The teacher's practical teaching level directly affects the guiding effect of his practical teaching. Therefore, teachers should be encouraged to actively participate in practical learning and related training to improve the level of practical teaching. The first is to receive training on case teaching, classroom discussion, scenario simulation, role play and other aspects. Some experts with rich experience and outstanding achievements can be invited for on-site demonstration, gradually deepen the teachers' understanding and grasp of the practical teaching in class, and finally achieve the goal of mastering all kinds of practical teaching methods and effectively applying them in the teaching process. The second is to attach importance to the research of practical teaching. Schools should appropriately increase the research projects of practical teaching in the teaching research projects, so as to promote teachers to improve the theoretical level of practical teaching. The third is to encourage teachers to make full use of virtual, simulation and other modern educational technology means, reform the traditional experimental teaching mode, improve the experimental teaching effect. Fourthly, schools should create conditions and opportunities, select and send some young teachers to public departments for part-time training, increase their practical experience in public management, and promote teachers to have a deep understanding of relevant theories and practices of public management. 


\subsection{Increase Funding for Public Administration Laboratory}

Public administration laboratory often has relatively limited funding for school construction, and it is difficult in laboratory construction. Therefore, on the one hand, we must constantly appeal to schools for the importance of public administration laboratory. On the other hand, we should broadly attract social investment, broaden financing channels, and strive to establish a rich and comprehensive experimental teaching platform. For example, we can apply for the ministry of education's industry-university cooperation and education project, purchase or jointly develop with enterprises such virtual experimental teaching platforms as e-government, public policy, public relations, public crisis and urban management, etc, to provide students with a variety of experimental content and simulation scenes, so that students can further improve relevant professional skills on the basis of virtual simulation scene experience.

\subsection{Strengthening the Construction of Off-Campus Practice Bases}

Schools should give full play to the advantages of personal resources, promote the "collective government building" and "school-enterprise cooperation", and find internships with the internship units to explore the multi-channel strategic cooperation. For example, the practice base provides convenience for practical teaching, provides positions for teachers to work and graduates, and provides certain support for graduate employment; At the same time, teachers can carry out research on the practical work of the practice base in the post-job training, actively provide administration consultation, write analysis reports, ,etc., and share the research results with the internship units to achieve deep cooperation.

The school can also invite government departments and business managers with rich practical experience to serve as part-time tutors outside the school, to guide students in the second classroom activities, to provide on-the-spot guidance for students' graduation internships, and to carry out practical seminars, which are used to teach students the administration of modern administration. Skills and practical skills to help students integrate public administration expertise with public administration practices and deepen their understanding of professional theoretical knowledge [12].

\subsection{Strengthen the Assessment of Practical Teaching Links}

For the whole practical teaching process, we must formulate a strict and reasonable evaluation system to strengthen the awareness of teachers and students' practical teaching quality. Students' practice results must have written internship reports or investigation reports. The instructors inside and outside the school should make a reasonable evaluation of the students' practical reports. The final practical results should distinguish the merits and demerits, and reward the outstanding ones. The effect should be appropriately supplemented with education to guide students to take practical teaching activities seriously and ensure that practical teaching receives real results.

\section{CONCLUSION}

All in all, the practical teaching of public management majors should take students as the main body, teachers as the mainstay, and use classrooms, laboratories, schools, and society as the carrier to build a scientific and reasonable practical teaching system, so as to improve students' practical ability and innovation ability, and cultivate compliance socially demanding high-level applied public management talents.

\section{REFERENCES}

[1] Li Na.,Research on the construction of practical teaching system of public administration majors in applied undergraduate colleges , Information Systems Engineering, vol.3,pp.156-157,2015.

[2] TAN Yu, CAI Zhiqiong, GUO Xinzhu, Enlightenment from the Practical Teaching System of Public administration majors in American Universities, Journal of Tianjin Vocational College of Business, vol. 4, pp.46-50,2016.

[3] Rich auspicious, Construction of Practical Teaching System for public administration majors, Education and Teaching Forum, vol. 3, pp. 170-172,2013.

[4] Liu Yiting, Research on the Construction of Teaching System of Public Administration majors in Colleges and Universities, Reform and Opening, vol.10, pp.93-95,2016.

[5] Li Jianbin, Discussion on perfecting the practice teaching system of public administration majors in colleges and universities, Journal of Inner Mongolia Normal University (Philosophy and Social Sciences), vol.42, pp.83-86,2013.

[6] Qiu Menghua, Research on the Construction of Practical Teaching System and Path Innovation in the Cultivation of Applied Talents_- Taking the public administration majors of Shanghai University of Engineering Science as an Example, Education and Teaching Forum, vol. 09, pp. 171-173,2016. 
[7] Zhang Xiaofeng, Innovation of the practical teaching mode of public administration majors, Science and Technology, vol. 6, pp.91-92,2017.

[8] Wang Shouwen, Research on Practice Teaching Innovation of public administration Discipline Based on Interdisciplinary Perspective, High Teaching Journal, vol.01, pp.10-13,2016.

[9] Shen Lijuan, Constructing a practical teaching model of public administration in STSUSC, Education Modernization, vol. 07, pp.23-26,2018.

[10] Wang Yongming, Gan Yuewen. On the Construction of public administration Practice Teaching System, Journal of Inner Mongolia Normal University (Educational Science Edition), vol.09, pp.150-152,2015.

[11] Wu Bo, Fu Zhiming, Yu Xiuqin, Research on the Characteristics and Countermeasures of Practical Teaching Mode of Public Administration Discipline in Teaching Applied Universities_-Based on the Investigation and Analysis of Ten Universities in Shanghai, Wuhan and Hangzhou, Tianjin Radio and Television University, vol.9, pp.57-61,2012.

[12] Lu Zhizeng, Research on the Innovation of Practical Teaching Mode of Public Administration Discipline in Colleges and Universities, Modern Trade and Industry, vol.12, pp. 285-287,2010. 